\title{
Kerkeenheid
}

\section{en meerdere kerkevergaderings}

Prof B. Spoelstra

\section{PROBLEEMSTELLING}

Die 20e eeuse vraagstuk van die "eenheid van die kerk" hang saam met die opkoms van die genootskaplike kerkbegrip uit die Rasionalisme gedurende die 18e eeu. Die Reglemente van De Mist (1804) en Koning Willem I in Nederland (1816) het met die eerste Sinode in 1824, praktiese beslag in Suid-Afrika gekry. Ironies genoeg het juis die idee van kerkeenheid binne een genootskap onmiddellik in die vorige eeu tot 'n menigte kerklike afskeidings in Suid-Afrika (Van der Watt 1977) en kerklike "denominasies" oor die wêreld gelei. By die genootskaplike kerkbegrip is volgens Rutgers die reëling, die struktuur "hoofdzaak, ja het eén en het al . . . het kerkverband is gelegen in de gemeenschappelijke onderwerping aan de reglementen". Hulle ag eenheid in belydenis wenslik, maar eenheid kan daarsonder so lank die sigbare struktuur van die genootskap ongeskonde bly. Vir die Gereformeerdes is eenheid in kerklike vorme wenslik, maar eenheid bly bestaan wanneer eenheid in vorm ontbreek, solank dieselfde Belydenis uitgeleef word (Rutgers 1822:38. 54 - 55; Bouwman 1934: 13: 18).

"Eenheid van die kerk" in organisasie en struktuur het by die GKSA 'n rol begin speel toe oor die GES, die Algemene Sinode, die Interkerklike gesprek tussen 'Afrikaanse Kerke' gepraat is. Tans word vanuit sekere kringe aangedring op geintegreerde klassisse op grond van die prinsipe van "geografiese kerkvergaderinge" (vgl Aanvullende Agenda Sinode Temba $1987: 58)$.

2. DIE STRUKTUUR VAN 'GEOGRAFIESE KERKVERGADERINGE'

Die "prinsipe van die geografiese kerkvergaderinge" word klaarblyklik van die term "naburige kerke" in art. $41 \mathrm{KO}$ afgelei. Tog oorheers eintlik die prinsipe van een kerklike "struktuur" en nie die van "prinsipe van geografiese kerkvergaderinge" nie wanneer op net een teologiese opleiding en een "Administratiewe Buro" in dieselfde asem aangedring word. Fnige groepering van kerke op grond van kultuur (etnisiteit) word as 'n res van "apartheid" en rassediskriminasie verwerp. GKSA-deputate vir die GES en ekumeniese sake van verskillende nasionale sinodes het op Nooitgedacht 9 September 1986 'n bloudruk probeer uitwerk wat ook op die sendingkonferensie van die Gereformeerde Kerk Noordbrug in 1987 en op die GTV-jaarvergadering 11 Augustus 1987 nageklink het.

Die opvatting verstaan die "eenheid van die kerk" geografies. In 'n bepaalde gebied het slegs geintegreerde kerke, kerkrade en meerdere vergaderings bestaansreg. Afsonderlike gemeentes sou slegs mag toegelaat word indien die "betrokkenes" die kerkraad self uitdruklik daartoe om pragmatiese redes versoek. Die beginsel van demokrasie en 
volksoewereiniteit mag dus wel differensiasie van gemeentes binne die strukturele geografiese eenheid toelaat, maar nie t.o.v. kerkvergaderinge nie.

\section{STROMINGE WAT DIE IDEE VAN STRUKTIJRELE EN GEOGRAFIESE KERKEENHEID GEVOED HET}

\subsection{Die Lutherse twee-ryke-leer}

Die Lutherse twee-ryke-leer reken die universele of ware kerk van God tot die onsigbare hemelregering van Christus. Parallel daarmee sorg die vors van die land vir die kerk as sigbare preekinstituut van predikers (Pfarrers) volgens die feodale stelsel: Eius regio cuius religio. Die sigbare kerk-organisasie behoort dus tot ' $n$ bepaalde geografiese land of politieke eenheid. Die Lutherse sekularisering van die sigbare kerk en skeiding van die onsigbare kerk het die kollegialisme begunstig (De Wet $1921: 23 \mathrm{v}$ ). Die Lutherse territoriale stelsel reken met "landskerke" waarby "geografiese" kerkvergaderinge pas. Dit bring die probleem na vore, byvoorbeeld m.b.t. Suid-Afrika. Suid-Afrika het byvoorbeeld in 1875 nog uit talle verskillende etniese en politieke eenhede bestaan totdat Britse imperialisme 'n geografiese eenheid vir alle Suid-Afrikaners gekoloniseer het. Is die koloniale geografie nou vir die kerke normatief en indien wel, waarom? Selfs in die GES speel die beginsel van 'n "territorial state" (RES $1984: 85,93$ ) 'n normatiewe rol. Wie polities en kerklik van holistiese eenhede (imperiums) uitgaan, kan geen genoee neem met nasionale of onafhanklike state en ook nie met plurale kerkvergaderinge nie.

3.2 Die Romeinse collegium licita en verenigingsreg van die $18 e$ eeu Die Romeinse reg ken die collegium licita in 'n bepaalde gebied. Die Aufklărung neem die outonomie van die individu as vertrekpunt en sê die lede verenig vrywillig in 'n sekere land (geografies) om 'n landskerk of volkskerk te vorm. So bepaal die vereniging in sy grondwet (konstitusie) sy doelstellings, bestuurswyse volgens wense van sy lede. Sommige Gereformeerdes dink ook aan die "Kerk" as 'n abstrakte eenheid, 'n kerkgenootskap, 'n regspersoon, genoem die "GKSA". Hierdie geografiese instituut openbaar homself in gemeentes. 'n Plaaslike kerk is ook weer 'n instituut of regspersoon met sy eie geografiese grense. Dus beslaan strukture van kerke, klassisse, partikuliere sinodes en "die sinode" "geografiese kerkvergaderinge" van "een kerk". Weinig kerkregtelikes het al erns gemaak met die feit dat die abstrakte idee van die "staat" of "kerk" as eenheid 'n produk van die rasionalisme in die $18 \mathrm{e}$ eeu is. Prof. Murray van die Universiteit Kaapstad sê: "Historici mag opmerk dat die term 'staat' (en dit geld ook vir eenheidskerk - B S) nie voor 1600 vir die benaming van politieke instellings gebruik word nie." Dit is eers Hobbes met sy Leviathan 1631 wat die opkoms van die moderne soewereine "staat" aandui wat doelbewus ook die "pluralisme" en "oorspronklike pluriformiteit van die Christelike Kerk" verdring. Die idee van die soewereine staat, hoogste owerheid of sinode as "sentrale liggaam" dateer na Rousseau. Die soewereiniteit van die "sentrale liggaam" verplaas die "rule of law" of soewereiniteit van die reg (Murray 1976: 9-16). 


\subsection{Die idee van 'n imperium}

Die Westerse mens vereenselwig strukturele eenheid met grootheid, mag en 'n veilige leefwyse. Dit blyk uit die Westerse ryksbou. Die Roomse monargale pousdom en ekumeniese konsilies is op politieke strukture van die Romeinse keiserryk geskoei (Plockl 1960; Spoelstra 1980). Tans beinvloed internasionalisme, sosialisme, ekumenisme en kommunisme weer die begrip kerkeenheid. Daar is 'n parallel tussen die idee agter die vVo en WRK. J Ridderbos suggereer dat hierdie organisatoriese idee van eenheid van heidense oorsprong is (Spoelstra 1978). Plaaslike kerke wat hulle op geestelike en konfessionele eenheid in Christus beroep, steek vaal teenoor hierdie "groot" eenheidstrukture af. Die moderne ideaal is daarom om gemeentes in kerkgemeenskap en kerkgemeenskappe in ekumeniese liggame saam te bondel.

\subsection{Platonisme}

Die Platonisme stel genade teenoor die natuur. Dit het vanuit die RoomsKatolisisme en Piëtisme die 20e eeu se Christendom beinvloed. Die "kerk" word sito-sito (as struktuur) met die liggaam van Christus vereenselwig en as alternatiewe gemeenskap teenoor natuurlike lewensverbande gestel. Die "kerk" staan bo en teenoor natuur, kultuur, volk, staat en regering. Die "kerk" is outoriteit wat soos pous Innocentius III in die Middeleeue regerings onwettig verklaar en nuwe regerings erken. Die kerk vorm struktureel 'n "alternatiewe" samelewing teenoor die "staat". Die Platonisme het in ons eie sendingwerk byvoorbeeld "gepreek" (genade) maar nie op sendingplase (natuur) geboer en werk verskaf nie.

\subsection{Die kollegialisme}

Die Aufklärung en rewolusie het die eenheid van die liggaam van Christus gesekulariseer en met kerklike verskynings- en regeringsvorme vereenselwig. Die denominasie is die kerk. Verenigings kan interdenominasioneel die "verskeurdheid van die kerk" ophef. Dit word beweer dat kerkgroeperinge die liggaam van Christus verskeur. Kerklike strukture soos die Wêreldraad van Kerke kan die liggaam van Christus weer heel. Eenheid word as imperatief vir ekumeniese eenheidorganisasie aangevoer asof Christus daarsonder nie net een liggaam sou hê nie.

\subsection{Skuldgevoel oor apartheid}

Talle Afrikaners het vanaf omstreeks 1980 'n skuldgevoel oor "apartheid" begin ervaar. Hulle skryf enige verwysing na verskille en verskeidenheid tussen Eerste- en Derdewêreld kerklike instellings aan rassediskriminasie toe. Sommige beskou selfs die opleiding te Hammanskraal as vrug van rassediskriminasie omdat "een kerk" "net een opleiding" vereis. In die VSA en CRC waar integrasie die opset beheers, eis die Indiane juis weer afsonderlike kerke en klassisse. (Vgl ook dieselfde beweging by Indonesiërs in Nederland, Maori's in NieuSeeland, ens).

"The precondition of Christian unity is the recognition and acceptance of diversity, plurality and difference. The ecumenical goal is unity in diversity, not uniformity. In as complex a human activity as religion, there can be no unity on any other terms. Those who cannot tolerate 
diversity (of creed, interpretation, practice, structure etc) must insist on separation in order to preserve a rigid identity" (Hodgson 1987: 232 233). Tog word die idee van een kerk onder een sinodale gesag (kollegialisme) gedurig weer as kerkeenheid en die WRK as "wêreldkerk" geïnterpreteer.

\subsection{Verskillende Belydende en Belydeniskerke irrelevant in 'n post- christelike wêreld}

Die sekularisering in Europa maak groot dele van die evangelie as "a pie in the sky" uit. 'n Kerk waarin Belydenis, Christus, Skrif, hiernamaals sentraal staan, het nutteloos en irrelevant geword. Die "kerk" moet nou "diesseitig" soos 'n party optree selfs al moet hy agterryer vir bepaalde politieke ideologieë met die oog op verandering in sosiopolitiek-ekonomiese bewegings speel. Dit veroorsaak dus ook 'n beweging om kerklike besture te sentraliseer sodat dit maklik gemanipuleer en gebruik kan word in sosio-politieke en ekonomiese aksies.

\section{BASIESE NORME}

\subsection{Die koninkryk moet kerkeenheid bepaal}

Die opmerking van Loisy dat Christus die koninkryk van God gepreek het, maar dat sy volgelinge daarvan die kerk gemaak het, bevat 'n element van waarheid (Spoelstra 1986 h.a. Ridderbos). Die koninkryk wys veral op God se heerskappy of regering (Ridderbos $1950: 41$ ) wat geloof in en gehoorsaamheid aan Christus en so die eenheid wat die kerk is, bewerkstellig (HK S. 21, 48; NGB 27, 29). Die dinamies-monargale heerskappy van Christus deur sy Woord en Gees (HK S. 21) is indikatief vir die regte begrip van kerkeenheid.

Die kerkbegrip in die vroeë Christelike kerke, by Rome en Calvyn neem Christus se koninkryk as uitgangspunt. Vir Rome val die kerk saam met die sfeer van die pous as verteenwoordiger van Christus se heerskappy. Vir Calvyn word die koninkryk gerealiseer waar die Woord van Christus as Hoof van sy kerk eerbiedig en die werke van die duiwel (soos dwaalleer) verbreek word (HK S. 48). Die kerk van Christus is daarom 'n organisme van gelowiges of eenheid in ware geloof. Die universele kerk van Christus (HK S. 21) word sigbaar in gelowiges wat lokaal vergader (NGB 28) en daar geregeer word (NGB 29,30,31). Die kerk is daarom nie 'n wetlike instelling of struktuur wat objektief bestaan en geografiese grense beslaan nie. Elke mens kan met dié norme van suiwer bediening van Woord, sakramente en tug (art. $29 \mathrm{KO}$ ) bepaal waar hy die ware kerk op ' $n$ bepaalde plek kry en by die gemeenskap aansluit (NGB 28).

\subsection{Die kerk is nie struktuur nie maar Godsvolk}

Wanneer die koninkryk (soos in Christus se prediking) voorop gaan, is die kerk die geroepe Godsvolk. Die Gereformeerde Belydenis ken die kerk as mense in universele en in lokale sin wat deur 'n ware geloof met Christus verenig is (HK S. 21; NGB 27-29). Die plaaslike gemeente wat die kenmerke van die ware kerk van Christus vertoon, is die universele kerk of liggaam van Christus op daardie plek (Snyman 1977 : 45). Volgens die Skrif word die een kerk of liggaam van Christus in die verskeidenheid van plaaslike kerke sigbaar. Die wesenlike eenheid in Christus is dus sinoniem met die wesenlike sigbare verskeidenheid van gemeentes. 


\subsection{Die volk bepaal nie reg of strukture in 'n monargie nie}

Wanneer die koninkryk en nie die kerk nie as basiese vertrekpunt geneem word, beteken dit dat die Koning monargaal reg vir sy kerk bepaal. Die kerk kan hoegenaamd nie biskoplik, hiërargies, demokraties of andersins reg neerlê nie. Die Kerkorde is gevolglik nie 'n bron van reg waaruit 'n "beginsel van geografiese kerkvergaderings" as imperatief afgelei kan word nie. Dit is slegs 'n ordereëling waardeur die reg wat Christus bepaal in kerkregering uitgeoefen moet word.

Die institusionele aspek van die gemeente (kerk) is die dienste wat Christus ingestel het om die kudde te versorg en te regeer (NGB 30; Matt $28: 17$; Hand $20: 28 ; 1$ Kor $12: 28 ;$ Ef $4: 11 \mathrm{v}$ ). Die kerkvergaderinge vind met die oog op die ampsbediening plaas. Dit staan sekondêr t.o.v. die ampte. Die opsiener-ouderling (presbiter) is die instrument wat die koningskap, die Woord van God in prediking, sakramente en dissipline moet bedien (Calvyn, Inst IV.3.i.-viii; NGB 7, 29). Wanneer hulle diens gehoorsaamheid aan Christus meebring, het die kerkregering geslaag en is selfs geen kerkvergadering nodig nie.

4.4 Die kerkraad is sekondêr en kerkvergaderings tersiêr ten opsigte van die ampte

Die kerkraad tree as sekondêre figuur in kerkregering na vore. Eers wanneer 'n growwe sonde of verharding voorkom, kom die ouderlinge in kerkraad saam om die sleutelmag te bedien (Calvyn, Inst IV.11.i-vi). Die wese van die kerk word bepaal deur die verhouding tot Christus (geloof en gehoorsaamheid). Die kerkregering moet hierdie verhouding, d.w.s. die wese van die kerk, beskerm. Die Gereformeerde kerkregering verskil derhalwe radikaal van die kollegialisme wat deur middel van 'n kerkorde of kerkwet die bestuur van die kerk aan kerkvergaderings en ampsdraers opdra en die kerkeenheid in daardie kerkvergaderings terugvind. Calvyn ontken kategories dat 'n konsilie die beeld van die kerk is (Inst IV.9.i). Die "eenheid van die kerk" kan dus onmoontlik in strukture van meerdere kerkevergaderinge uitgedruk word. Daarbenewens is die kerk en instelling van die dienste God se werk, terwyl die strukture deur mense ingestel is en op verantwoordelikheid van mense steun (Velema 1971: 15).

\subsection{Die kerk is nie 'n statiese struktuur met eienskappe nie}

Die mode om "die eenheid van die kerk" as norm te neem, is verdag. Dit beskou die kerk as 'n staties-objektiewe instituut en ontleed sy struktuur om "eenheid" as een van die eienskappe van die kerk te isoleer. Die kerk staan in die genitief asof dit eintlik om eenheid gaan. Daarteenoor is die kerk self volgens die Belydenis per definisie eenheid in Christus (NGB 27; HK S. 21).

\section{Opmerking oor prof. W. J. Snyman}

J. Ridderbos verwerp die verklaring van Joh $17: 21$ asof organisatoriese kerkeenheid daarin voorgeskryf word (Spoelstra $1978: 2-4$ ). Die kerk kan nie in wese eenheid wees en tegelyk eenheid in 'n struktuur moet verwesenlik nie.

Snyman (1977: 80v, 109) maak 'n sprong in sy denke. Hy skryf vyf artikels in Die Kerkblad 13 Julie 1966 tot 10 Augustus 1966. Die eerste twee stel op Skrifgronde die eenheid van die universele liggaam van Christus wat 


\section{In die Skriflig}

in elke plaaslike kerk (die gelowiges) tot openbaring kom. Hy ontken dat "kerk" volgens die Skrif 'n versameling (organisasie) van gemeente kan wees. Die derde artikel (27 Julie '66) verwys na Hand 15 en lei "kerkverband" as struktuur rasioneel uit die wese van die kerk af. In die vierde artikel argumenteer hy vanuit "kerkverband" dat "eenheid" tot op ekumeniese vlak deur "samespreking" verwesenlik moet word. Die artikel van 10 Augustus 1966 oor "Kerk, taal en volk" handel oor "jong kerke" alwaar "kerk" vergadering van gelowiges maar ook 'n informele institusionele "saambinding" of "kerkverband" beteken. Indien Snyman "kerk" hier vir 'n eenheid van gemeentes gebruik, doen hy dieselfde as wat die Kerkorde van De Mist 1804 en Reglement van 1816 gedoen het en wat hy in sy eerste twee artikels as 'n verkeerde kerkbegrip afgewys het. Sy stelling van 'n "roeping" om "kerkeenheid" in strukturele "verbande" tot op ekumeniese vlak te herstel is gevolglik hoogs aanvegbaar. Wanneer hy "kerke" met ander "kerke" oor verdeeldheid laat praat om tot "eenheid" te kom, beteken "kerk" vir hom nie meer plaaslike of universele kerk soos in die Skrif nie, maar wat die kollegialiste onder genootskap verstaan.

Die verwarring word veroorsaak wanneer die begrip "kerkverband" as sinoniem vir "kerkeenheid" sowel as vir "meerdere vergaderings" gebruik word (vgl Snyman t.a.p.; Bouwman 1934 : 1 - 83 en Rutgers 1882). Du Plooy (1982) het duidelik aangetoon dat kerkverband eerder die geloofseenheid in Christus is en nie met kerkstrukture geidentifiseer kan word nie.

\section{6 "Kerkverband" nie 'n struktuur nie}

Gereformeerdes gebruik soms die begrip "kerkverband" op dieselfde wyse as wat kollegialiste die "algemene" of sinodekerk teenoor die plaaslike kerk stel (vgl. bv. art, 20 KO). "Volk" en "volksverband" of "gesin" en "gesinsverband" druk 'n relasie uit sodat volk en volksverband nie van mekaar losgemaak kan word nie. Tog word kerkverband teenoor kerk gestel met die kerkraad as "orgaan" van die plaaslike kerk en meerdere vergaderings op kollegialistiese wyse as organe van kerkverband (Spoelstra $1979: 47-49$ ). Du Plooy toon tereg aan dat kerkverband met die universele kerk as eienskap van elke plaaslike kerk gegee is. Die eenheid kan op verskillende maniere beleef word maar nie met strukture of meerdere vergaderings vereenselwig word nie (Du Plooy 1982 : 116v, 407). Afsonderlike klassisse en provinsiale sinodes, verskeidenheid in die eenheid, organisasie op grond van taal- en volksverskille, doen geen afbreuk aan die eenheid in kerkverband nie (Du Plooy 1982 : $361-363$ ). Kerkverband is voorwaarde vir kerke om in klassisse (sinodes) saam te kom en mag nie met meerdere vergaderings geildentifiseer word nie.

4.7 Die meerdere vergaderings van die 16e eeu struktureer nie kerkeenheid nie

Meerdere kerkevergaderings as middel van kerkregering het funksioneel tot stand gekom om die eenheid in leer en lewe, d.w.s. die kerk, te bevorder en te bewaar (NGB 32). De Bres, die opsteller van die NGB, het nie die meerdere vergaderinge van ons Kerkorde voorsien nie. Hy was gekant teen die Franse Kerkorde van 1559 uit vrees dat 'n sinodepous Christus weer uit die kerke sou verdring. Meerdere vergaderings be- 
hoort dus nie tot die wese van die kerk nie, maar is nodig soos Nederlandse kerkregtelikes sê om die "welwese" van die kerke in kerkverband te bevorder (Bouwman 1934:9). Gereformeerde meerdere vergaderings behoort juis die vryheid en selfstandigheid van elke plaaslike kerk te bevorder (Bouwman 1934: 14).

Die funksie van meerdere vergaderings geskied nie aanvullend op 'n eie terrein t.o.v. die kerkraad nie. Dit beoog basies om die ampsbedieninge te ondersteun sodat die plaaslike kerk die beeld van die ware kerk van Christus (volgens die bekende drie kenmerke van art. $29 \mathrm{NGB}$ ) sa] vertoon. Dit verskil ingrypend van die rasionalisme met sy statiese institusionele kerkbegrip en abstrakte begrip van kerkeenheid in 'n organisasie (vgl Spoelstra $1986: 11-14$ ).

\section{DIE WESE, PLEK EN ROL VAN GEREFORMEERDE MEERDERE VERGADERINGS}

\subsection{Die vertrekpunt}

Wanneer ons die dinamiese regering (koninkryk) van Christus deur sy Woord en Gees instrumenteel bedien deur ' $n$ verskeidenheid van dienste, dienaars en vergaderinge, as uitgangspunt neem, moet kerkeenheid bestaan in die mate waarin individue en die gemeente aan Christus en so aan God en sy Woord en Wet gehoorsaam is. Sonde bedreig die eenheid m.b.t. leer en lewe. Wanneer die ouderling sy bediening van die Woord met vrug vervul, het die kerkraad niks te doen nie (Matt $18: 15$ - 17; KO art 72,73$)$. Die presbiteriale kerkreg gaan net soos Rome van die monargale beginsel in die opsiener uit. Sodra die ekskommunikasie of sleutelmag bedien moet word, reken Calvyn vanwee die menslike faktor dat die sleutelmag nie deur "een of 'n paar" nie maar deur die raad van ouderlinge uitgevoer moet word (Inst IV.11.i-vi; Bevestigingsformulier vir Ouderlinge).

Hieruit kan ons aflei dat onder ideale omstandighede waar die individuele ouderling met vrug regeer, sou geen kerkraad nodig wees nie. Die kerkraad behoort daarom nie tot die wese van die kerk nie. Die kerk is orde so lank dit as geloofsgemeenskap die Woord en Gees gehoorsaam. Die kerkraad is eers sekondêr nodig om sensuur toe te pas (Vgi. B. C. Milner, aangehaal Spoelstra: $1982: 239$ ).

Ons moet gevolglik vra: Indien die kerkraad nie die "eenheid van die kerk" konstitueer of kerkeenheid bewerkstellig nie, maar slegs 'n middel is om die gegewe eenheid d.m.v. kerkregering te bewaar, hoe kan "meerdere vergaderinge" ooit die "eenheid van die kerk" uitdruk of struktureer?

\subsection{Hoe het meerdere vergaderinge tot stand gekom?}

\subsubsection{Kerkorde en kerkeenheid}

Sedert die Hervorming het Geneefse, Franse, Waalse, Duitse en Nederlandse kerke dikwels sonder kerkrade, slegs met predikante, as komplete, selfstandige en onafhanklike kerke bestaan. Van Kerkordes wat kerk institueer, was nie sprake nie. Godsdiensgesprekke en konvente is ad hoc gehou om belydenisverskille op te los. Bepaalde Belydenisstukke en Kategismusse is aanvaar om kerkeenheid as geloofsgemeenskap in Formuliere en Eenheid uit te druk. Calvyn het byvoorbeeld die 


\section{In die Skriflig}

dienste (ampte) uit die Skrif afgelei (Inst IV.3), maar nie in die Skrif bepaalde voorskrifte vir 'n Kerkorde daarin gevind nie. Kerkorde staan sekondêr t.o.v. die Belydenis en daarom kon plaaslike kerke vrywillig kerkordelike ooreenkomste aangaan (Pont 1981:9). Kerkeenheid en "kerkverband" word wesenlik deur die belewing van die Belydenis en nie deur Kerkorde bepaal nie. Eers wanneer die verenigingsreg in die $18 \mathrm{e}$ eeu die kerk as regspersoon in die enkelvoud na vore bring, vat 'n kerksentriese benadering pos. Die Kerkorde skep volgens die beskouing eenheid, konstitueer die kerk as instituut en bepaal hoe die kerk as organisasie sy ampte inrig en homself regeer.

\subsubsection{Die oudste Kerkordes pretendeer nie kerkeenheid nie}

Die proloog van die Geneefse Kerkorde van 1541 (gerevideer 1561) stel die doel van die Kerkorde om die leer suiwer te bewaar en die kerk in goeie orde te hou, die jeug te onderrig en armes te versorg. Daar kom geen dogmatiese of filosotiese motief na vore om die "eenheid van die kerk" (struktureel) te verwesenlik nie (Pont 1981 : 23). Uit die Kerkorde van Genève kan ons egter nie te veel aflei nie. Dit was 'n kompromis tussen Calvyn en die Raad van Genẽve en staan eintlik op rekening van laasgenoemde.

Die Franse Kerkorde van 1559 waarby Calvyn inspraak gehad het, is egter van suiwer kerklike herkoms. Ook daar gaan die heel eerste artikel van die bestaan van ' $n$ aantal afsonderlike kerke uit en bepaal dat die instelling van vergaderings in artikels 2 tot 5 nooit daartoe mag lei dat die kerke oor mekaar heerskappy sal uitoefen nie.

Ons verskil dus van prof. Pont wat hierin " 'n kerklike orde . . . vir 'n nasionale kerk" lees. Hy sê self: "Die plaaslike gemeente word hier dus gesien as 'n ware, volkome gemeente of kerk wat alle eienskappe besit wat aan die kerk eie is" (1981 : 48 - 50). Hy kan slegs uit die verenigingsreg aflei dat die orde "al die gemeentes saamvat in eén geordende geheel" en dat elke gemeente 'n "onderdeel van die geheel" word. Die Kerkorde van 1559 sê nerens dat 'n kerkgenootskap tot stand kom nie (Pont 1981 : 48v, art. 2).

Die kerkordelike ontwerp van die Konvent van Wezel 1568 wil nie met 'n kerkorde 'n kerkgenootskap stig nie, maar wil verseker dat alles ordelik en eerbaar in die leer, orde en kerkregering sou gaan (Voorrede, Pont 1981 : 74). Kerke kom in klassisse saam sodat elke kerk kan weet met wie hy in voorkomende sake moet beraadslaag om tot 'n gemeenskaplike oordeel te kom (Pont 1981 : 75, art. 2). 'n Algemene provinsiale sinode of algemene vergadering moet gemeenskaplike sake soos predikanteopleiding en versorging reèl (art. 3). By Emden 1571 speel strukturele eenheid ook geen rol nie.

Die motief met kerkvergaderings is dus nie strukturele eenheid nie, maar om plurale plaaslike kerke van raad en advies te bedien en tweedens om sekere gemeenskaplike sake gesamentlik te behartig. Hier is geen sprake om tot een nasionale "kerk" ter wille van "kerkeenheid" te verenig nie. Gevolglik verskil ons ook hier van Pont wat sê dat Emden die "fondamente vir die Nederlandse Hervormde Kerk" gelẽ het deur 'n sinodale vergadering op 'n "presbiteriale-sinodale sisteem" uit te werk $(1981: 92,93)$. Die interpretasie berus op die kerkbegrip van die 
Nederlandse Hervormde Kerk wat die Reglement van 1816 geskep het. Die kerkordes van die $16 \mathrm{e}$ eeu reken nie met 'n oorkoepelende strukturele kerkeenheid nie maar met dinamiese kerkregering om die eenheid in geloof te bewaar. Pont benadruk self dat die kerkordes die gemeente aan die kenmerke van die ware kerk wou laat beantwoord (Pont 1981 : 10v, 16).

\subsubsection{Kultuur en nasionale faktore bepaal klassikale indeling}

Die eerste Sinode van Emden 1571 maak in die eerste ordende artikels veelvuldig van uitdrukkings soos "Nederlandse, Franse en Engelse kerk" melding (art 2, 3, 8; vgl. "Nederlandse kerken" en "dienaren", gemeentes met Franse en Nederduitse "sprake", "Waalse kerken" met hulle eie klassis, art. 2, 3, 8, 9, 10, 11). Indien "geografiese indeling" 'n prinsipe is en "kerkeenheid"' kulturele faktore uitskakel, kan ons hierdie kerkordelike inrigting nie verklaar nie.

Die kulturele verskeidenheid word klassikaal en in die Formuliere van Eenheid eerbiedig. Alhoewel Latyn destyds algemene taal was, talle predikante by Calvyn in Frans en met die Franse Kategismus en Belydenis opgelei was en die politiek-sosiaal-kerklike kontak tussen Engelse en Nederlandse kerke intiem was, word plurale kerkvorming skering en inslag. ' $n$ Eie klassis vir Engelse kerke word noodsaaklik beskou (Emden 1571 art. 12). Daar was kulturele verskeidenheid kleiner as tussen Eerste en Derde Wêreldkerke. Weliswaar is binne die verskeidenheid, tweejaarlikse "versameling van alle Nederlandse Kerken" (art. 9) nodig geag. Hierdie algemene "sinode" word hoegenaamd nie doel of uitgangspunt op homself asof dit voortaan klassisse en kerke saambind nie (soos Pont suggereer nie). Die vertrekpunt bly plurale kerke in plurale klassikale samekomste terwyl algemene "versamelingen" (in meervoud) gemeenskaplike sake soos eenheid in Belydenis versorg. Sinodes bly geleenthede vir kerkregering op sterkte van 'n "gemeen accoord" (Belydenis en art. 86 DKO). Ek bedoel "geleenthede" hoegenaamd nie "terloops" nie, soos my vriend Du Plooy my verkeerd verstaan het (1979 : 118). "Geleentheid" wil slegs beklemtoon dat hier geen staande struktuur geinstitueer is nie, maar dat die kerke ad hoc saamkom, werk afhandel en dan uitmekaar gaan.

Ons verskil van Bouwman wat sẻ dat 'n kerklike vergadering sy mag aan die deelnemende kerke ontleen (1934:19). Tog het hy gelyk wanneer hy die kerke as wesenlike handelende subjek in die meerdere vergadering na vore bring (1934:18). Hy verstaan nie onder "klassis" of "sinode" 'n struktuur wat deur die kerkorde as 'n regspersoon langs of selfs teenoor kerkrade geskep is om namens die grotere geheel of "kerkverband" op te tree nie. Bouwman se skerp onderskeiding tussen die "macht" van 'n kerkraad en 'n meerdere kerkevergadering t.o.v. oorsprong, wese, duur en doel is korrek (Bouwman 1934: 22). Ons sou die "mag" liewer nie uit strukture nie maar uit die koninkryk en Christusregering wou aflei.

Dit is irrelevant of ' $n$ mens ' $n$ klassis (sinode) as 'n byeenkoms van kerke of van kerkrade beskou. Die kerk handel na buite slegs deur die kerkraad. Wie op sterkte van art. $41 \mathrm{KO}$ wil argumenteer dat juis die "kerk" en nie die kerkraad nie in klassis teenwoordig is, kleef aan die idee dat kerke in die klassis 'n nuwe eenheid daarstel. Die gedagte dat kerke 
d.m.v. verteenwoordigers "lid" word van byvoorbeeld 'n ekumeniese "liggaam" soos die GES om die "eenheid van die kerk" daar te stel, strook met die rasionalistiese en kollegialistiese beginsel van vrywillige vereniging tot nuwe genootskappe deur middel van delegasie.

\subsubsection{Meerdere kerkvergaderinge bedien kerkregering in plurale kerke} en konstitueer nie kerkeenheid nie

'n Mens staan verstom oor hoe wyd die $18 \mathrm{e}$ eeuse strukturele idee van "eenheid" vandag polities, kerkllk, ekonomies posgevat het. Die Afskeiding van 1834 het daaraan nie ontkom nie. Waar'n sentrale eenheid, 'n sinodekerk as ware kerk teenoor die "valse" NHK te staan gekom het. Die Doleansie (Kuyper met sy "kerk as instituut") verplaas die "eenheid" van 'n Nederlandse Hervormde Kerk met die begrippe soos "kerkverband" en "meerdere vergaderings". Die plaaslike kerk met sy kerkraad kom bipolêr teenoor kerkverband met sy meerdere vergaderings te staan (Spoelstra: 1964:35 v; 1967:28 v; 1977:45 v).

Gedurende die Reformasie het die kerke met klassikale en ander vorme van sinodes in sake wat uitsluitlik by die kerkraad behoort "advies" gegee, maar ten opsigte van die Belydenis uitsprake gedoen waarmee gekonformeer moes word. Die kerke het in die samekomste altyd kerkregering, d.w.s. funksionaliteit, "welwese" van plaaslike kerke as gestaltes van die liggaam van Christus op die oog gehad. Die sinodes pretendeer nooit dat hulle ontbrekende kerkeenheid naburig, provinsiaal, nasionaal of internasionaal daarstel nie.

Toe die GKSA in 1946 ' $n$ volwaardige ekumeniese sinode bepleit het, het die GKN dit afgewys omdat kerkwees en kerkregering in 'n bepaalde politieke, geografiese en kultuurmilieu plaasvind. Volgens F. L. Rutgers dra "kerkverband" selfs 'n bepaalde "nationaal karakter" (1882:26). Calvyn het met Lutherane en Anglikane konfessionele eenheid gesoek en sou, met die oog daarop enige konvent, waar in die werreld ook al, gaan bywoon om saam tot dieselfde belydenis te kom (Snyman 1977 : 99). Tog het Calvyn nooit beweer dat byvoorbeeld Geneve by die Franse Sinode van 1559 moet inskakel om "eenheid" te verwesenlik nie. Hy ontken baie duidelik dat 'n konsilie (sinode) die beeld van die kerk is. Sinodes beklee net 'n funksionele plek (Inst. IV.9). Die huidige gedagte dat kerkeenheid in kerkvergaderinge en kerkstrukture vergestalt moet word, is nie deel van die Reformasie nie maar kom uit die nuwe kerkreg van die Aufklarung op.

Indien Christus die enigste Hoof van ook die sigbare kerk is, kan gevra word waarom die eenheid ook nog in 'n sinodale gestalte uitgedruk moet word. Rome identifiseer die koninkryk van Christus met die institusionele eenheid van die pouslike monargie. As sinodes vir kerkregering saamkom, gebeur dit vir 'n bepaalde funksie. Om die kerk met die vorm van kerkregering te identifiseer; om die "eenheid van die kerk" in strukture vir kerkregering geografies en ekumenies af te lees, kom neer op die drogredenasie van petitio principi waardeur die geheel, in een enkele aspek, die regering, opgaan (vgl. Rom 12:6-8; 1 Kor 12:28; 1 Tim 3 ens.).

Vanuit die perspektief van die koninkryk van God waar Jesus Christus die enigste Hoof van sy Kerk is (Van der Walt 1976; Spoelstra 1986), maak 
konsentriese (art. $30 \mathrm{KO}$ ) klassikale, provinsiale en algemene sinodale vergaderinge slegs sin wanneer hulle besluite daartoe dien dat die universele kerk in elke plaaslike kerk (NGB 29) vergestalt word. Kerkeenheid in Christus kom dan juis in 'n pluraliteit van kerke, kerkrade en sinodes na vore. Die Gereformeerde Belydenis ken net een Raad vir elke kerk (vgl. art. 30 NGB; Bevestigingsformulier vir Ouderlinge). Tog kry talle gereformeerdes swaar om in te sien dat meerdere vergaderinge (met konsentries krimpende bevoegdheid) in wese nog altyd kerkraadsvergaderinge is. Of 'n kerk alleen of saam met ander kerke (kerkrade) kragtens kerkverband vergader, die betrokke kerk is nog altyd self daarby as subjek betrokke. Daar is dus in wese nie iets soos "die beginsel van geografiese klassisse" nie.

5.2.5 Die 16e eeuse Gereformeerde Kerkordes erken etnisiteit en institusionele pluriformiteit in die een kerk van Christus

Ek gebruik "pluriformiteit" hier opsetlik en letterlik om die idee van meervoudige verskyningsvorme van die een kerk te beklemtoon terwyl die basiese en wesenbepalende eenheid in geloof en Belydenis behou word. Calvyn erken selfs ware kerke onder die "vorm" van 'n valse pousdom (Inst IV.2.xiii).

Ons het reeds aangetoon dat die Sinode van Emden 1571 etniese kerke erken. Die Dordtse Sinode konstitueer as 'n Nederlandse nasionale Sinode saam met 17 "kolleges" van buitelandse Gereformeerde Kerke wat elk volgens land van herkoms selfstandig bly en nie in die sinode oplos nie. Meervoudige kerklike groeperinge bestaan op nasionale gronde alhoewel daar volkome eenheid in Christus is. Die eenheid word nie struktureel afgedwing nie. Die Kerkorde van 1619 eerbiedig verskeidenheid in vorme tussen kerke in verskillende lande (art. 85) so lank konfessionele eenheid bestaan en reken met die werklikheid dat binne die een geografiese en politieke Nederlande "tweederley sprake gesproken wort". Daarom kon die "Kerken der Duytscher en Waalscher Tale op haer selven hare Kercken-raet, Classicale Vergaeringhen ende particuliere Synoden" onderhou (DKO art. 51). Hulle kon ook as sodanig na die Nasionale Generale Sinode deputeer. Die roepende kerk moes in dieselfde plek met die "naast gelegene kerk, die van eene andere taal is" onderhandel (DKO art. 50). Waalse en Nederlandse predikante en ouderlinge in dieselfde dorp moes so ver moontlik maandeliks vergader "om goede eendracht en correspondentie met malkanderen te houden" (Pont 1981 : 182).

Die kerkinrigting van die Reformasie erken dus die realiteit van etniese verskeidenheid in kerke, klassisse en sinodes. Vir uitsprake oor die leer en aanverwante sake waar die wesenlike eenheid van geloofsbelydenis op die spel was, moes egter 'n algemene sinode gehou word. Toe die owerheid nie die sinode wou toelaat nie, is kerkeenheid van 1619 tot 1816 gedien deur middel van deputate van korrespondensie tussen onderskeie en verskillende partikuliere sinodes (DKO art. $48 \mathrm{KO}$ ).

In die GKSA het korrespondensie tussen verskillende etniese sinodes nog nie eers begin nie. Namate die besef van pluraliteit en pluriformiteit verswak deur die strewe na sentraliserende kerkstrukture sal "korrespondensie" al meer sy betekenis verloor. Die GKSA het tussen 1958 en 1979 korrespondensie as "eenheid in die kerkverband" met "prioriteits- 
volgorde" eenheid "in gemeenskap" t.o.v. Skrif, Belydenis en Kerkorde beklemtoon (GKSA Acta 1976:313-319;1979:45v) as "eenheid in diens, leer en tug" (1979: 40). Tog praat Sinode 1979 van "kerkverband" in terme van strukture en wil meerdere vergaderings tot op die vlak van 'n "volwaardige" ekumeniese sinode "institueer" (1979: 46, 47). Korrespondensie word dan deur struktuur verplaas en die plurale besef in 'n sentrale eenheidskonsep verloor.

\subsubsection{Die konfessionele kerkbegrip waarsku teen oorbeklemtoning van kerkordelike strukture}

Wyle prof. W. J. Snyman en talle van sy studente het vanuit die Skrif opnuut aangetoon dat God se kerk God se volk en derhalwe gelowige mense in plaaslike en universele sin is. So is die plaaslike kerk die universele kerk, komplete kerk, op daardie plek (Snyman 1977: 78; Coetzee 1965 : 306, 318; Du Plooy 1979 : 6 - 29; $1982: 64$ - 120). Die Belydenis ken nie die kerk as 'n sigbare of voorstelbare genootskapstruktuur nie. In ons kringe leef ' $n$ verwoestende afkeer teen independentisme asof Robert Browne (1550 - 1636) met sy emigrantekerk uit Engeland in Middelburg (Nederland), omstreeks 1580 die enigste eksponent van independentisme was. Die Engelse kerke van àLasco en kongregasionalisme van Robert Parker verskil egter radikaal van dié van Browne.

Robert Parker het direkte invloed op die Dordtse Sinode en Voetius uitgeoefen. Die Kongregasionaliste erken in hulle Kerkordes, naamlik die Cambridge Platform 1646 (VSA) en Savoy Declaration 1658 (London) naas die selfstandigheid van die plaaslike kerk (ecclessia prima) hoe noodsaaklik onderlinge gemeenskapsbeoefening tussen partikuliere kerke is. Sinode is egter nie 'n nasionale of landskerk nie, maar gemeenskapsoefening tussen kerke in sinodes (ecclesiae ortae). Die primëre kerk is collectio singulorum fidelium in unam concregationem. Ecclesiae ortae is die versameling en combinatio van plurale kerke in een coetum wat sinode genoem word (Deddens $1985: 48$ ). Sinodes moet voorkom dat predikante dwaal, wanbestuur uitskakel en geleentheid vir appèl gee. Die Cambridge Platform sê die Skriftuurlike kerkvorm is "only congregational (the term Independent, we approve not); therefor neither national, provincial nor classical . . there is no greater church than a Congregation which may ordinarily meet in one place" (Deddens $1985: 50)$. Sinodes is nodig om gemeenskap met mekaar te onderhou en nodig "to the welbeing of churches, for the establishment of truth and peace therein". Robert Parker en Voetius het baie gemeen (Bouwman $1937: 45,49 \mathrm{v}, 105,110,118$ ).

Die kollegialisme wat kerkeenheid met geografiese kerkvergaderings vereenselwig, het die idee van plurale kerke en pluriforme kerkvergaderings binne dieselfde kerkverband (eenheid in diens, leer en tug) uit die reformatoriese erfenis gewurg. Geen "beginsel van geografiese klassisse" het die pluraliteit opgehef nie. Die kerkraad is in die Skrif gegee (NGB 30.31) terwyl die sogenaamde "meerdere vergaderings" ter wille van die "welwese" van die kerke ontwerp is maar nooit normatief vir die kerkregering gemaak mag word nie (art 32 NGB). Die selfstandigheid en kompleetheid van elke plaaslike kerk bly voorbehoud by die aangaan van kerkordelike ooreenkomste (Parys 1559 art. 1; Emden 1571 art. 1; DKO art. 84). 
6. ENKELE GEVOLGTREKKINGS M.B.T. MEERDERE KERKEVERGADERINGS EN KERKEENHEID

6.1 By die groepering van "naburige" kerke in klassisse (art. 41 KO) was nie "geografies" nie maar die gegewe natuurlike en organiese karakter waarin die een kerk van Christus in die baie plaaslike kerke na vore kom deurslaggewend.

6.2 Kerke staan nie los van kultuur nie en kerklike gemeenskap vereis 'n bepaalde taalmedium. Die kerkregering in die plaaslike kerk vind in ' $n$ bepaalde kulturele en sosiale gemeenskap van mense plaas. Die naasgeleë en belangrikste meerdere vergaderings soos klassis en partikuliere sinode vereis intieme kommunikasie wat nie van milieu, taal en kultuur geskei kan word nie. Die algemene sinode behartig die prinsipiële gemeenskaplike sake soos belydenis wat universeel en nie partikulier van aard is nie.

6.3 Die universele band tussen alle gelowiges en tussen kerke in Christus laat hulle met mekaar korrespondeer oor taal en kultuurgrense heen. Dit is die eenheid in 'n ware geloof wat deur die Woord en Gees gewerk word (HK S. 21). Gesuiwer van alle kollegialistiese tendense behoort slegs belydenis en aanverwante sake in 'n algemene sinode tuis (vgl. art. $30 \mathrm{KO}$ ).

6.4 Kerke leef nie in verskillende meerdere vergaderinge geisoleerd nie. Die meerdere vergaderings is tydelike byeenkomste en nie verdelende strukture nie. Die belewing van kerkverband (koinonia of korrespondensie) moet deur regstreekse skakeling tussen kerke en in vergaderings deur middel van deputate (DKO art. 48, 52) onderhou word. Dit is opmerklik dat hierdie vorm van gemeenskap nog slegs deur die "ouer" kerke (bv. GKSA 1964 : 269(6) en Part. Sinode Noord-Transvaal 1981) beklemtoon is terwyl deputate uit ander sinodale verbande aandring om pluraliteit met geintegreerde kerkstrukture uit te skakel. Deputate vir korrespondensie tussen klassisse en nasionale (partikuliere) sinodes (art. 48) kan die belewing van kerkverband en kerkeenheid stimuleer sonder dat paternalisme of heerskappyvoering in terme van art. $84 \mathrm{KO}$ in gedrang kom.

6.5 Nasionale Sinodes te Potchefstroom 1961 en 1964 het lynreg teenoor heersende rassistiese politiek belangrike lyne getrek. Weliswaar is daar leemtes soos waar sogenaamde Kleurlinge "etnies" gegroepeer is. Die vraag is nietemin, bloot fenomenologies beskou, of die Kleurlinge nie eie gemeentes met byvoorbeeld eie liturgiese patrone begeer nie. Indien dit die geval is, is dit logies dat daardie kerke in klassis sal saamkom om mekaar in dit wat hulle eie vorm van kerkwees is, te help. Liturgie is byvoorbeeld nie 'n saak van die plaaslike kerk nie, maar van kerke in kerkverband.

6.6 Meerdere vergaderings soos klassisse, sinodes en "algemene sinode" word te maklik deur sommige sterk struktureel i.p.v. federaalfunksioneel vertolk. Die betekenis van die oorspronklike Nederlandse woord "samekomste van kerke" is verlore. Bewys hiervan kom voor in die gebruik van benaminge soos "Sinode Middellande" of "Sinode Suidland" asof dit kerkstrukture met name is. Opvallend het die samekomste van kerke in Potchefstroom nie so 'n naam nie. Ons is blykbaar nie meer in staat om te praat van byvoorbeeld kerke in die Middellande, 
Sinode Temba September 1987 nie.

6.7 Die kerke met die Eerste Wêreld as agtergrond het 'n bepaalde kerklike vergader-patroon in kerkverband uit 'n homogene taal en kultuur daargestel. Hulle onderneem saam 'n menigte koöperatiewe bystandaksies van sustentasie, opleiding, tehuise, Bybelvertaling, ens, ooreenkomste met bv. die PU vir CHO, interaksie met ander Afrikaanse kerke ens. Wie 'n stelsel van "geografiese klassisse" wil forseer, vergryp hom aan hierdie werklikheid en bring art. $84 \mathrm{KO}$ in gedrang. Nuwe klassikale indelings en geografiese kerkvergaderinge moet die resultaat van natuurlike ontwikkeling wees en ontstaan op die vlak waar dit tuishoort (art. $30 \mathrm{KO}$ ). Dit moet nie ideologies "kerkeenheid" uit 'n sentrale gesagspool, bv. algemene sinode wil afdwing nie.

6.8 Eerste en Derde Wèreldkerke openbaar duidelik eiesoortigheid in taal, wyse van aanpak, belangstelling, probleemvelde, prosedures. Selfs die begrip vir en gebruik van Kerkorde en kerklike orde lê nie eners nie. Kerke in die Derde Wêreld neem maklik verlief dat een deputaat 'n rapport opstel en sake buite die opdrag van die vorige sinode om daarin voorstel. Sommige sendelinge beweer dat kerke van die Derde Wêreld nog baie min met die Belydenisskrifte identifiseer of verinheemsing daarvan probeer bevorder of deur die Skrifstudies uitsprake oor probleme wat aan die swart Christene eie is, probeer doen. Agter swart kerklike aktiwiteite figureer nog dikwels "blanke" raadgewers op 'n tipiese Westerse wyse en met Westerse voorskrifte.

6.9 Die Piëtistiese sending het kerstening en verwestering ideologies vermeng. Ek het al elders probeer aantoon watter rol kolonialisme (verwestering) gespeel het in byvoorbeeld die sendingkrisis gedurende die vorige eeu tussen die Venters en die predikante Postma en Cachet uit Europa wat sending binne kolonialistiese konteks benader het (Spoelstra sj : 151-192). Struktuurdwang wat formele kerkeenheid binne die multi-etniese realiteit probeer verwesenlik, sal meer konflik veroorsaak as wat dit sal oplos. Nugtere evaluering maak klassisse wat naby aan die kerke se eie besondere sosio-ekonomiese leefwêreld geleè is, tans nog onontbeerlik.

6.10 Die Gereformeerde kerke het lank volgens politieke indeling in Algemene Vergaderings (in plaas van klassisse en partikuliere sinodes) saamgekom, min ramings, klassikaal en sinodaal opgelê; plaaslike vryheid en verantwoordelikheid hoog gerespekteer ens. Teen 1924 het kerke in Transvaal en Kaapkolonie klassikaal en part. sinodaal gedifferensieer maar die ovs en Natal het met die algemene vergaderingpraktyk tot ongeveer 1942 volhard. Getrapte afvaardiging na sinodes het eers na 'n eeu plaasgevind. "Geografiese klassisse" sou meebring dat die kerke uit die Derde Wêreld dadelik by hierdie Eerste Wêreldmodel met sy grœeiende sinodokratiese inslag sal moet inskakel. Hulle sal dus geen eie kerkordelike patroon volgens eie behoeftes en vermoë kan ontwikkel nie.

6.11 Objektiewe analise van die situasie m.b.t. Eerste en Derde Wêreldkerke toon (a) dat in verskillende klassisse verskillende tale gepraat word; (b) Afrikaans as medium vir selfs talle gegradueerde swart predikante onhanteerbaar is; (c) Engels as kerktaal vir Afrikaanse 
predikante onaanvaarbaar is; (d) die Afrikaans-Gereformeerde tradisie eerder Europees-Nederlands as Engels is; (e) die Eerste Wêreldkerke hoë ramings bekostig in verskillende meerdere vergaderings, terwyl Derde Wêreldkerke nog kwalik op plaaslike vlak kerklike bydraes na vermoè insamel en selfs predikante en gegoede lidmate nie persentasie van inkomste gee nie; (f) geen Gereformeerde teoloog uit die Derde Wêreld het nog 'n doktorsgraad onder leiding van Gereformeerde teoloe behaal nie; (g) die ervaringsvlakke van ouderlinge en diakens in Eerste en Derde Wêreldkerke lê te ver uitmekaar. Om klassisse vir opleiding te wil gebruik, bots met die wese van 'n klassis en hou die gevaar van paternalisering vanuit 'n vreemde kulturele milieu in.

6.12 Die Hervormde teoloè beklemtoon in die interkerklike gesprek 'n basiese waarheid dat kerk-eenheid wesenlik deur geloof in Christus bepaal word. Om die imperatief vir kerkeenheid struktureel en institusioneel te verstaan, verloèn die Reformasie, die Gereformeerde Belydenis en Kerkorde. Kuyper se onderskeiding van "kerk as organisme" en "kerk as instituut" het waarskynlik die institusionele opset van die kollegialisme begunstig en die dinamiese karakter van die kerk as belydende gemeenskap of organisme (art. 28, 29 NGB) verswak.

6.13 Die kerk is mense wat in Christus gemeenskap (koinonia) beoefen. Elke mens het in sy totaliteit (liggaamlik, geestelik, kultureel, ekonomies, sosiaal, intellektueel, emosioneel, ens.) deel aan Christus en aan mekaar. Daar is dus 'n verband tussen mens-wees, kerk-wees, tussen godsdiens en kultuur, natuur en genade wat kerk-wees nie ophef nie en kerkvergaderinge allermins kan ignoreer (vgl Bennett 1987; Schrotenboer 1986).

6.14 Probleme moet by die Eerste en Derde Wêreldkerke op plaaslike vlak geidentifiseer word en daar aangespreek word. Indien daar behoefte aan kommunikasie en korrespondensie van die een met die ander is, moet inisiatief geneem word om met mekaar te skakel (art. 48 Ko). Wat nie plaaslik opgelos kan word nie, kan eers daarna sinvol na meerdere vergaderings gevoer word.

6.15 Ons moet 'n funksionele praktiese kerkregering nastreef. Strukturele vorme sal dan vanself ontwikkel, aanpas of wysig. Om te dink dat wanneer ons 'n struktuur geskep het, ons daarmee 'n probleem opgelos het, is wensdinkery. Strukture skep iets soos die huidige GES - 'n struktuur vir eenheid, maar in die praktyk 'n ervaring van verdeeldheid. As daar nie apartheid in SA en homofilie in die GKN was nie, het die GES geen agenda gehad nie.

\section{BIBLIOGRAFIE}

Acta Synodi GKSA (Potchefstroom) $1955: 298 ; 1958: 68 ; 1961: 526,534 ; 1964: 370 \mathrm{v}$; $1976: 313-319 ; 1979: 35-47$.

Bennett, R. A. 1987: The Power of Language in Worship. Theology Today. January p $546 \cdot 551$.

Bouwman, H. 1934: Gereformeerd Kerkrecht. Deel II. Kok

Bouwman, M. 1937: Voetius over het gezag der Synoden. Amsterdam. Bakker.

Calvyn, J. Institusie van die Christelike Godsdiens (vgl. verkorte weergawe A. Duvenage 1951, Sacum). 


\section{In die Skriflig}

Deddens, D. 1985 : Synoden bij Robert Parker en in de Congregationalistische Kerkorden van 1648 en 1658. Bezield Verband. Bundel aangebied aan J. Kamphuis. p $46-57,396-399$.

De Wet, C. J. H. 1921: Die Kollegiale Kerkreg. H. A .van Bottenburg

Du Plooy, A. le R. 1982: Kerkverband. 'n Gereformeerd-kerkregtelike Studie. Ongepubliseerd. PU vir CHO.

Du Plooy, A. le R. 1979: Ekklesia en Meerdere Vergaderinge. Ongepubliseerd. PU vir $\mathrm{CHO}$.

Geref. Kerke in die Middellande 1987: Sinode Temba, Aanvullende Rapport. Report of Deputies for Ecumenical Matters.

Hodgson, D. C. : Ecclesia of Freedom. Theology Today. Vol XLIV Nr 2. Julie 1987. Kuyper, A. sj: Dictaten Dogmatiek. Locus de Ecclessia. 2e druk. Kok.

Loots, P. J. 1962: Pluralisme in Staat en Kerk. Ongepubliseerde proefskrif, UK.

Murray, A. H. 1976: Die post St Bartholomeusnagliteratuur en die plurale tradisie in die Suid-Afrikaanse staatsinstellings en Protestanse Kerke. In die Skriflig. Jrg 10, Nr 39. Sept 1976.

Plockl, W. M. 1960: Geschichte des Kirchenrechts. Wien, Munchen.

Pont, A. 1981: Die historiese agtergronde van ons kerklike reg. Kittal.

Ridderbos, H. 1950: De komst van het koninkrijk. J. H. Kok.

Rutgers, F. L. 1882: Het Kerkverband der Nederlandsche Gereformeerde Kerk gelijk dat gekend wordt uit de handelingen van den Amsterdamschen Kerkraad in den aanvang der $17 \mathrm{e}$ eeuw. J. H. Kruyt.

Schrotenboer, P. G. 1986: The Church and Ethnic Groups. RES Missions Monthly November.

Snyman, W. J. 1977: Nuwe en Ou Dinge. Uit die skat van die Koninkryk. Pro Rege.

Spoelstra, B. 1964: Die verteenwoordiging van die diakonale amp op meerdere vergaderings. Ongepubliseerd. PU vir CHO.

- - 1967: Die gesag van meerdere kerkvergaderings. In die Skriflig. Jrg 1, Nr 3.

- - B 1977: Die gesag van die Sinode. In die Skriflig. Jrg 11, Nr 43.

- - 1978: Eenheid van die kerk. Redaksioneel. In die Skriflig. Jrg 12, Nr 45, Maart.

- - 1979: Diskussie (oor kerkverband). In die Skriflig. Jrg 13, $\mathrm{Nr} 52$, Desember.

- - 1980: Die beginsel in Art. $30 \mathrm{KO}$. In die Skriflig. Jrg 14, Nr 55, September.

- - 1982: Calvin's Canon Law and influence on Churches in South Africa Calvinus Reformator, PU vir CHO, p 232 - 258.

- 1986: Het ons kerk-wees in strukture gestol? In die Skriflig. Jrg 20, $\mathrm{Nr} 80$. Desember.

Spoelstra sj: Kolonialisme en ons sendingkrisis in die vorige eeu. Die Saailand is die wêreld. Jubileum-uitgawe Hammanskraalse Teol. Skool.

Van der Walt, J. J. 1976: Christus as Hoof van die Kerk en die presbiteriale kerkregering. Pro Rege.

Van der Watt, P. B. 1977: Gemeentes en nogmaals gemeentes. NGKB, Pretoria.

Velema, W. H. 1971: Aangepaste Theologie. Amsterdam. 